\title{
29. In vitro Transformation of Hamster Embryo Cells with Tryptophan Pyrolysis Products*)
}

\author{
By Shozo Takayama,**) Yoichi Katoh,**) Machiko Tanaka,**) \\ Minako NAGA0,***) Keiji WAKABAYASHI,***) \\ and Takashi SUgImURA***)
}

(Communicated by Toshio KurokawA, M. J. A., June 14, 1977)

Recent studies on the mutagenic activities of the smoke condensate and the charred surface of fish and meat in which Salmonella. typhimurium was used have been reported (Nagao et al., 1977a). Subsequently, it was revealed that the mutagenic principles were formed by pyrolysis of proteins, not of carbohydrate, nucleic acid, nor vegetable oil (Sugimura et al., 1977b). Strong mutagenic activity was detected in the pyrolysis products of amino acids, especially tryptophan. 3-Amino-1,4-dimethyl-5H-pyrido [4,3-b] indole (Trp-P-1) and 3-amino-1-methyl-5H-pyrido [4,3-b] indole (Trp$\mathrm{P}-2)$ were isolated as the mutagenic principles in the pyrolysis products of D,L-tryptophan (Sugimura et al., 1977a).

Since 1976, a reliable in vitro bioassay technique with cryopreserved primary hamster embryo cells has been developed and reported to have a high correlation between morphological transformation and the reported carcinogenicity of the chemicals (Pienta. et al., 1977a, b). We adopted this assay method to examine whether the pyrolysis products of D,L-tryptophan would induce the transformation or not. This paper deals with the first successful report of the transformation by tryptophan pyrolysates.

Basic fractions of D,L-tryptophan pyrolysate, Trp-P-1, and Trp$\mathrm{P}-2$, were prepared as described previously (Sugimura et al., 1977a). The transformation assay was carried out according to the method of Pienta (Pienta et al., 1977a, b). In this method, the cryopreserved primary cultures of Syrian Golden hamster embryo cells were used as the source of target and feeder layer cells. Usually four days. before use as a feeder culture, an ampoule of cryopreserved primary

*) This work was supported in part by grants from the Ministry of Education, Science and Culture, the Ministry of Health and Welfare, and Nissan Science Foundation.

**) Department of Experimental Pathology, Cancer Institute, 1-37-1, KamiIkebukuro, Toshima-ku, Tokyo 170.

***) National Cancer Center Research Institute, 5-1-1, Tsukiji, Chuo-ku, Tokyo 104. 
cells was rapidly thawed. The cells were seeded into a $75 \mathrm{~cm}^{2}$ flask containing $20 \mathrm{ml}$ Dulbecco's modified Eagle Medium supplemented with $20 \%$ fetal bovine serum and were refed daily. The cells were then irradiated with 5,000 R. The cells were immediately washed with Hank's solution. The washed cells were trypsinized and seeded at $6 \times 10^{4}$ cells per $50 \mathrm{~mm}$ dish in $2 \mathrm{ml}$ medium in the number of dishes required for the bioassay.

For use as target cells in the standard bioassay, an ampoule of cryopreserved cells from a pretested culture was rapidly thawed and seeded into a $75 \mathrm{~cm}^{2}$ flask containing $20 \mathrm{ml}$ medium and incubated at $37^{\circ} \mathrm{C}$. The medium was changed daily and when the culture was approximately 80-90\% confluent, it was trypsinized. About 500 cells contained in $2 \mathrm{ml}$ medium were seeded into $50 \mathrm{~mm}$ plastic dishes which had been seeded 24 hours previously with X-irradiated feeder cells. The next day, graded doses of test chemicals were added to the cultures in $4 \mathrm{ml}$ amounts to obtain the desired final concentrations of the chemicals in the culture medium. Control cultures were similarly treated with medium alone, or with dimethylsulfoxide (DMSO).

The cultures were incubated for eight days without disturbing or refeeding. They were then washed twice with Hank's solution, fixed with methanol, and stained with Giemsa.

Table I. Transformation of cryopreserved hamster embryo cells by basic fraction of tryptophan pyrolysate, Trp-P-1 and Trp-P-2

\begin{tabular}{|c|c|c|c|c|c|}
\hline \multirow{2}{*}{ Chemical } & \multirow{2}{*}{$\begin{array}{l}\text { Treatment* } \\
(\mu \mathrm{g} / \mathrm{ml})\end{array}$} & \multirow{2}{*}{$\begin{array}{l}\text { Number } \\
\text { of } \\
\text { dishes } * *\end{array}$} & $\begin{array}{c}\text { Transformed } \\
\text { colonies }\end{array}$ & \multirow{2}{*}{$\begin{array}{l}\text { Percent } \\
\text { colony } \\
\text { forming } \\
\text { efficiency }\end{array}$} & \multirow{2}{*}{$\begin{array}{l}\text { Percent } \\
\text { transform- } \\
\text { ation }\end{array}$} \\
\hline & & & $\begin{array}{l}\text { Surviving } \\
\text { colonies }\end{array}$ & & \\
\hline $\begin{array}{l}\text { Tissue culture } \\
\text { control }\end{array}$ & - & 9 & $0 / 538$ & 11.96 & 0 \\
\hline DMSO & $0.2 \%$ & 9 & $0 / 551$ & 12.24 & 0 \\
\hline \multirow{3}{*}{$3 \mathrm{MC} * * *$} & 0.1 & 9 & $1 / 459$ & 10.20 & 0.22 \\
\hline & 0.5 & 9 & $1 / 460$ & 10.22 & 0.22 \\
\hline & 1.0 & 8 & $2 / 369$ & 9.23 & 0.54 \\
\hline \multirow{3}{*}{$\begin{array}{c}\text { Basic fraction } \\
\text { of tryptophan } \\
\text { pyrolysate }\end{array}$} & 5 & 9 & $1 / 542$ & 12.04 & 0.18 \\
\hline & 10 & 9 & $3 / 523$ & 11.62 & 0.57 \\
\hline & 25 & 9 & $0 / 222$ & 4.93 & 0 \\
\hline \multirow{3}{*}{ Trp-P-1 } & 0.1 & 9 & $2 / 412$ & 9.16 & 0.49 \\
\hline & 0.5 & 9 & $3 / 223$ & 4.96 & 1.35 \\
\hline & 1.0 & 9 & $0 / 43$ & 0.96 & 0 \\
\hline \multirow{3}{*}{ Trp-P-2 } & 0.1 & 9 & $3 / 505$ & 11.22 & 0.59 \\
\hline & 0.5 & 9 & $7 / 459$ & 10.20 & 1.53 \\
\hline & 1.0 & 9 & $0 / 368$ & 8.18 & 0 \\
\hline
\end{tabular}

* Treatment was for eight days. ** Each dish was seeded with approximately 500 target cells. *** Positive control. 
The transformed colony formation by the basic fractions of D,Ltryptophan pyrolysate, Trp-P-1 and Trp-P-2, are shown in Table I. Trp-P-1 had a fairly strong cell toxicity. The colony-forming efficiency decreased remarkably at the concentration of $1 \mu \mathrm{g} / \mathrm{ml}$ of TrpP-1. Trp-P-2 was less toxic.

Significant numbers of the transformed colonies were observed in the dishes with the basic fraction of D,L-tryptophan at a level of $10 \mu \mathrm{g} / \mathrm{ml}$. The dishes with Trp-P-1 and Trp-P-2 at a concentration of $0.5 \mu \mathrm{g} / \mathrm{ml}$ also showed a significant number of the transformed colonies. Colonic formations with the three were dose-dependent. As seen in Fig. 2, the cells in a transformed colony exhibited the three-dimensional growth with extensive random-oriented growth and a criss-crossing of cells at the periphery of the colony. Moreover, the center of the transformed colonies showed a dense piling of cells. These cells were usually more basophilic. The in vivo tumorigenicity of the transformed cells in vitro is now under investigation.

The correlation between the capacity to form morphological transformation and the carcinogenicity of chemicals was about $90 \%$ according to Pienta's experience (Pienta, 1977a). There is also a high correlation between the carcinogenicity and the mutagenicity (McCann et al., 1975, Sugimura et al., 1976). The mutagenicity of the basic fractions of D,L-tryptophan pyrolysate, Trp-P-1, and Trp$\mathrm{P}-2$, has been already demonstrated in a bacterial system. Therefore,

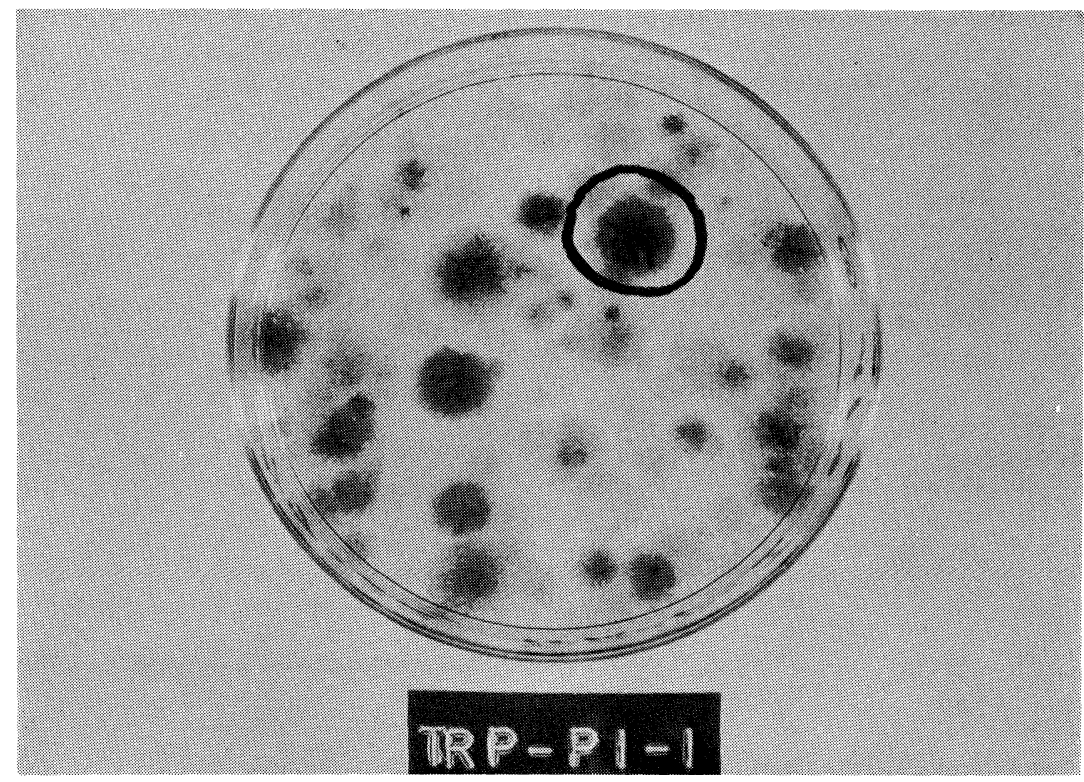

Fig. 1. Gross appearance of a fixed and Giemsa-stained dish treated with Trp-P-1 containing a transformed colony (circular sign). 


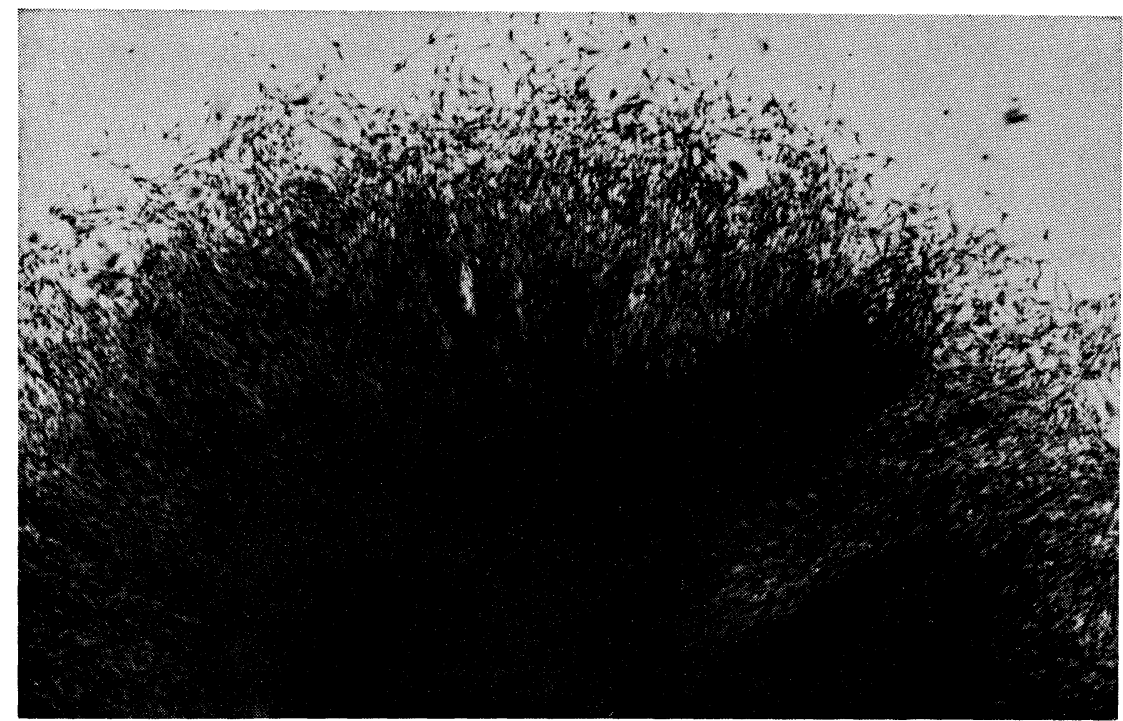

Fig. 2. Morphological transformation of hamster embryo cells induced by Trp-P-1. Note the random disoriented cell growth at its periphery.

Giemsa $\times 30$.

it is very likely that the basic fractions, Trp-P-1 and Trp-P-2 from tryptophan pyrolysate, exert carcinogenicity in in vivo experiments which are being carried out.

\section{References}

McCann, J., Choi, E., Yamasaki, E., and Ames, B. N. (1975) : Proc. Natl. Acad. Sci. U. S., 72, 5135-5139.

Nagao, M., Honda, M., Seino, Y., Yahagi, T., and Sugimura, T. (1977a) : Cancer Letters, 2, 221-226.

Nagao, M., Yahagi, T., Kawachi, T., Sugimura, T., Kosuge, T., Tsuji, K., Wakabayashi, K., Mizusaki, S., and Matsumoto, T. (1977b) : Proc. Japan Acad., 53, 95-98.

Pienta, R. J., Poiley, J. A., and Lebherz III, W. B. (1977a) : Proc. Third Internat. Symp. on Detection and Prevention of Cancer, May 1976, New York, N. Y., Marcel Dekker, Inc. (in press). (1977b) : Int. J. Cancer, 19 (in press).

Sugimura, T., Kawachi, T., Nagao, M., Yahagi, T., Seino, Y., Okamoto, T., Shodo, K., Kosuge, T., Tsuji, K., Wakabayashi, K., Iitaka, Y., and Itai, A. (1977a) : Proc. Japan Acad., 53, 58-61.

Sugimura, T., Nagao, M., Kawachi, T., Honda, M., Yahagi, T., Seino, Y., Matsushima, T., Shirai, A., Sawamura, M., Sato, S., Matsumoto, H., and Matsukura, N. (1977b) : Origin of Human Cancer, Cold Spring Harbor Laboratory Symposium, Cold Spring Harbor (in press).

Sugimura, T., Sato, S., Nagao, M., Yahagi, T., Matsushima, T., Seino, Y., Takeuchi, M., and Kawachi T. (1976): Overlapping of Carcinogens and Mutagens; Fundamentals in Cancer Prevention, Univ. Tokyo Press, Tokyo. 